\title{
KONSTRUKSI KALIMAT TRANSITIF \\ DALAM BERITA DARING MERDEKA.COM EDISI JANUARI 2019: KAJIAN LEXICAL FUNCTIONAL GRAMMAR
}

\author{
Invandri Kusuma \\ Universitas Diponegoro \\ Invandri.k@gmail.com \\ Submit, 03-11-2019 Accepted, 29-12-2019 Publish, 29-12-2019
}

\begin{abstract}
ABSTRAK
Penelitian ini mengkaji sifat konstruksi sintaksis kalimat transitif dalam berita daring Merdeka.com edisi Januari 2019. Konstruksi kalimat dalam penelitian ini dipengaruhi oleh adanya proses afiksasi. Proses afiksasi mengubah struktur menjadi beberapa argumen yang berbeda dari sebelumnya. Sementara pelesapan argumen sering terjadi untuk menyembunyikan objek atau pelaku sebagai objek. Analisis LFG berbasis argumen berdasarkan struktur memperhitungkan sifat kompleks dari struktur yang tidak biasa. Penyediaan data menggunakan metode simak dan dalam menganalisis data menggunakan metode agih distribusi. Data bersumber dari penggunaan kalimat pada berita daring Merdeka.Com secara tertulis. Hasil penelitian ini verba mengalami proses afiksasi pada fungsi predikat untuk menentukan argumennya. Beberapa kata tidak mengalami proses afiksasi untuk membentuk argumen lebih dari dua. Subjek yang sama dalam induk kalimat dan anak kalimat membentuk X-Comp pada kata formal.
\end{abstract}

Kata Kunci: Kalimat Transitif, Lexical Functional Grammar, Berita Daring, Verba

\section{ABSTRACT}

This study examines the syntactic nature of the transitive sentence construction in the January 2019 edition of Merdeka.com online news. The sentence construction in this study is influenced by the affixation process. The affixation process changes the structure into several different arguments from before. While obscene arguments often occur to hide objects or actors as objects. Argument based Lexical Functional Grammar analysis based on structure takes into account the complex nature of unusual structures. Provision of data using the listen method and in analyzing data using the distribution distribution method. The data is sourced from the use of sentences in Merdeka.Com online news in writing. The results of this study verbs undergo an affixation process on the predicate function to determine their arguments. Some words do not undergo the process of affixation to form more than two arguments. The same subject in the parent sentence and clause form the X-Comp in the formal word.

Key words: Transitive Sentences, Lexical Functional Grammar, Online News, Verbs 


\section{PENDAHULUAN}

Bahasa Indonesia merupakan salah satu bahasa yang unik dari struktur sintaksisnya. Konstruksi kalimat Bahasa Indonesia yang masih belum ketat dalam strukturnya membuat bahasa ini menjadi ladang penelitian yang menarik. Hal ini tidak lepas dari peran pengguna bahasa Indonesia cenderung terpengaruh dari bahasa daerahnya masing-masing dan bahasa asing. Masalah ini tidak lain karena peran balai bahasa yang menempatkan bahasa nasional merupakan bahasa yang luwes sesuai kebutuhan pengguna dan dapat memudahkan masyarakat seluruh Indonesia. Keraf (1984) mengatakan bahwa masa perkembangan dan pembangunan nasional tersebut bahasa-bahasa daerah masih amat diperlukan untuk memperkaya bahasa indonesia yang tertama dalam memperkaya perbendaharaan terutama kata-kata dan bentuk tata kalimatnya.

Kalimat-kalimat bahasa Indonesia memiliki karakteristik sebagai berikut: (1) kalimat terdiri dari satu klausul, (2) kalimat memiliki komponen yang sangat lengkap, (3) komponen cenderung terjadi dalam urutan, dan (4) kalimat dalam bahasa Indonesia jarang mengandung interogasi atau penyangkalan tetapi banyak penjelasan. Dalam kaitannya dengan karakteristik (3) di atas, bahwa komponen yang terjadi dalam urutan yang paling umum, predikat selalu ditempatkan setelah subjek atau sebaliknya dengan minim objek pada bahasa Indonesia (1996). Urutan paling umum terjadi karena pengaruh dari subjek-predikat pembentuk komplemen. Namun, berdasarkan data dianalisis predikat juga dapat terjadi sebelum komplemen atau fungsi lainnya. Dengan demikian, letak predikat pada bahasa Indonesia bisa terjadi di kiri atau kanan subjek yang akan memengaruhi objeknya. Dengan kata lain, struktur subjek-predikat-objek dan objek-predikat-subjek diterima dalam bahasa Indonesia.

Konsisten dengan masalah di atas, Purwo (1989) menegaskan bahwa Indonesia adalah bahasa yang memungkinkan SVO dan OVS yang dipengaruhi karena bentuk predikatnya dalam kalimat, Sugono (1985) menjelaskan bahwa predikat untuk membentuk argumennya bisa merubah konsrtuksi sebaliknya. Fakta-fakta bahwa bentuk argument pada bahasa Indonesia terpengaruh karena adanya proses afiksasi pada predikat sehingga akan merubah atau bahkan menambah jumlah argument kalimat transitif ke dalam beberapa klasifikasi seperti kalimat bitransitif atau monotransitif. 
Maka peneliti tertarik untuk meneliti pola kalimat transitif Bahasa Indonesia menggunaka Lexical Fungtional Grammar.

Penelitian tentang struktur bahasa Indonesia oleh Polinsky \& Potsdam (2007) meneliti tentang sintaksis Bahasa Indonesia dikaji menggunakan peran semantik; Wagiati (2013) mengkaji tentang tipe-tipe konstruksi predikat dalam Bahasa Indonesia; Shiohara (2012) mengkaji tentang aplikatif dalam tata baku Bahasa Indonesia; Arka (2014) mengkaji tentang penggandaan dan pembelakangan dalam argumen Bahasa Indonesia; dan Moeljadi et.al (2016) mengkaji tentang kopula dalam klausa di dalam Bahasa Indonesia. Adapun dalam penelitian ini mengkaji pola penggunaan verba Bahasa Indonesia dalam tulisan, yakni mengkaji pola transitifitas verba Bahasa Indonesia dalam berita daring Merdeka.com.

\section{METODE PENELITIAN}

Penelitian ini merupakan deskriptif kualitatif yang bertujuan untuk mengungkapkan berbagai informasi struktur kalimat dengan gambaran teliti, penuh dan secara cermat. Peneliti menggunakan data istilah kebahasaan dari media massa untuk mengkaji pola struktur bahasanya. Bahasa yang diteliti merupakan Bahasa Indonesia dalam berita daring Merdeka.com.

Data disediakan dengan cara menyimak secara mendalam kalimat dalam berita daring. Metode dan teknik yang digunakan dalam penelitian adalah metode agih dengan cara faktor-faktor penentu diambil dari bahasa dengan teknik pendistribusian fungsi kalimat. Data-data yang diteliti berupa struktur kalimat dalam berita daring Merdeka.com edisi Januari 2019.

\section{HASIL PENELITIAN}

\section{Argumen pada Verba Transitif}

Nomina dikategorikan menjadi tiga kelompok: benda umum, kata ganti dan nama. Secara umum kategori kata benda yakni: mati, bukan manusia dan manusia yang didasarkan pada tiga kelompok utama dalam bahasa Indonesia: misalnya 'buah' untuk kata benda mati, 'ekor' untuk kata benda bernyawa bukan manusia dan orang untuk kata benda manusia. Kata kerja memiliki kategori tiga kelompok: intransitif yang memiliki salah satu argumen, transitif yang memiliki dua argumen dan opsional transitif 
yang memiliki wajib tunduk argumen dan satu argumen opsional objek seperti 'Adi makan [nasi]'. Selain itu penggunaan kalimat pasif paling banyak terpengaruh dari proses infleksi morfologi yang menjadi kunci pola kalimat intransitif maupun transitives dalam bahasa Indonesia.

Kalimat aktif dan pasif menyangkut beberapa hal: (1) macam verba yang menjadi predikat, (2) subjek dan objek, dan (3) bentuk verba yang dipakai. Pemasifan dalam bahasa Indonesia dilakukan dengan dua cara: (1) menggunakan verba berprefiks di- dan (2) menggunakan verba tanpa prefiks di-. Tidak semua kalimat aktif dapat dijadikan pasif. Kalimat yang dapat diubah menjadi kalimat pasif adalah kalimat aktif yang mempunyai objek memiliki kategori kata benda. Kalimat perintah (command) dan kalimat seru (exclamation) juga tidak dapat dijadikan pasif. Jika kita gunakan simbol S untuk subjek, $\mathrm{P}$ untuk predikat, dan $\mathrm{O}$ untuk objek, maka kaidah umum untuk pembentukan kalimat pasif dari kalimat aktif dalam bahasa Indonesia adalah sebagai berikut:

1)

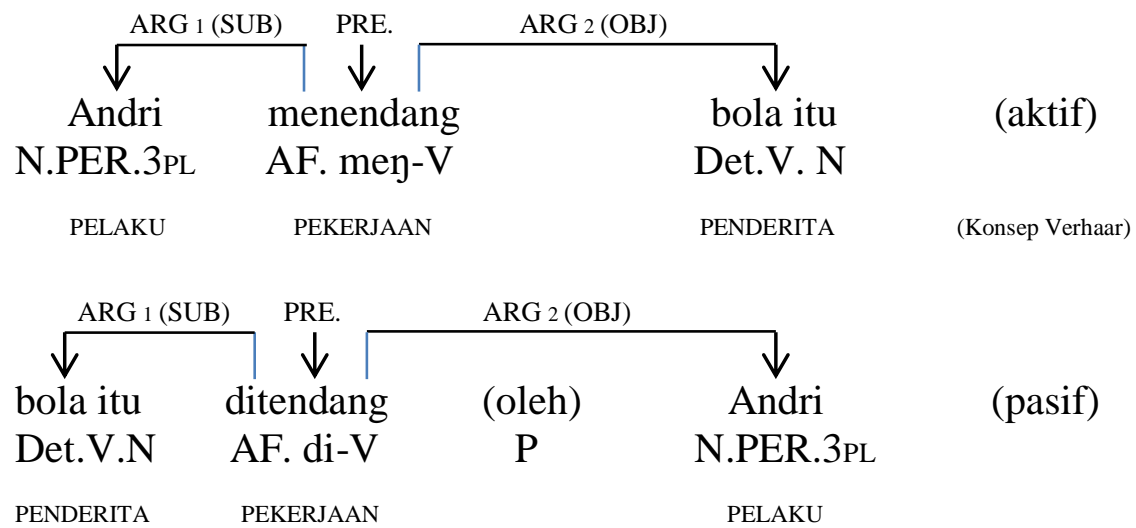

Pemasifan diatas dengan melakukan peran proses afiksasi morfologis pada kata kerja. Kalimat bentuk pasif menggunakan afiksasi mey- pada predikatnya untuk membentuk dua argumen. Argumen pertama merupakan agen nomina yang menjadi PREED1, pelaku yang mengendalikan atau memengaruhi argumen kedua sebagai $\mathrm{PREED}_{2}$ berupa orang yang melakukan kegiatan fungsi predikat. Objek pada data (1) merupakan frasa determiner, yakni frase penunjuk dari [PREED’BOLA']. Sedangkan argument kedua berupa [ASPECT 'OLEH'] dengan [PREED 'ANDRI'] yang dipengaruhi oleh fungsi subjek. Kedua data tersebut menggunakan pola pembentukan 
kalimat SVO. Pada konsep Verhaar (2012) memberi nama subjek sebagai 'pelaku', fungsi predikat merupakan 'pekerjaan' dan fungsi objek sebagai 'penderita'.

Pada data (2) frasa preposisi yang sebelumnya menjadi objek kini berpindah sebelum predikat berfungsi sebagai subjek penderita. Sedangkan fungsi subjek mulanya diisi oleh orang ke tiga sebagai pelaku kini berpindah fungsi sebagai objek pelaku. Pembentukan kalimat aktif menjadi pasif terbentuk karena pengaruh afiksasi dari morfem $d i$ - pada fungsi predikat tersebut. Sedikit berbeda dengan data di bawah ini pada kasus yang sama.

3)

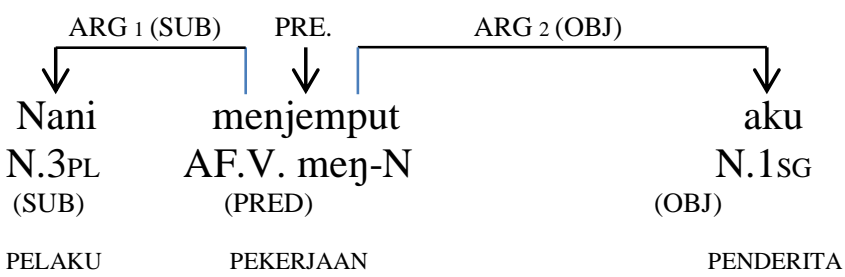

4)

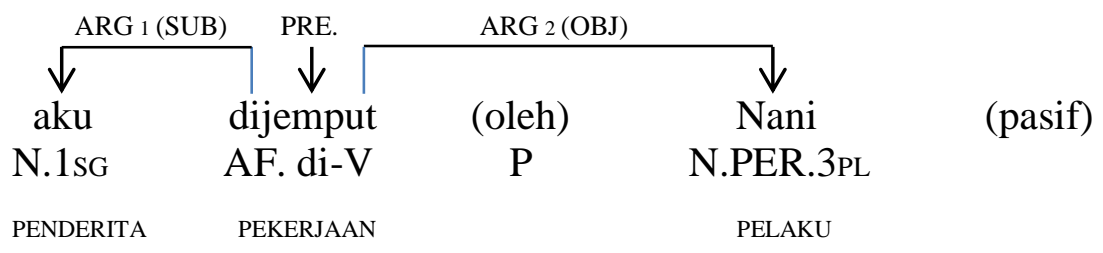

Kalimat data (3) memiliki kaidah yang sama dengan klasifikasi kalimat aktif transitif pada data (1). Namun jika kalimat itu dipasifkan akan mengalami perubhan secara sintaksis. Kedua argument yang berfungsi sebagai subjek [FREED 'NANI'] dan objek [FREED'AKU'] dimiliki oleh predikat berupa kata benda manusia dengan peran yang sama yakni SVO. Sehingga ada proses penambahan kata 'oleh' setelah predikat sebagai bentuk modifikasi objek manusia. Fungsi kata 'oleh' pada kalimat itu menjadi preposisi dari objek manusia. Kata tersebut memiliki peran sebagai penunjuk spesifik oleh pelaku yang memengaruhi dan berdampak pada penderita.

\section{Jenis Argumen}

Indonesia adalah bahasa yang memiliki struktur konfigurasi lemah dalam hal struktur gramatik. Konsep argumen pada bahasa ini terkadang tidak simetris dengan teori yang telah ditemukan oleh pakar bahasa, maksudnya kita dapat membuat berbagai kemungkinan untuk memilih jenis argumen. Teori X-bar yang memiliki konsep biner bercabang akan terasa rumit jika menggunakan data yang kompleks pada argumennya. 
Bahasa Indonesia tidak terlalu ketat dalam argumen yang berupa DP dan menghilangkan argumen. Kebebasan penggunaan argumen pada bahasa ini keluar dari jalur struktur tatabahasa dan lebih mengedepankan semantiknya.

\section{Argumen Kata Benda}

Argumen yang berupa kata benda banyak ditemukan pada bahasa Indonesia. Untuk membentu dua argumen kalimat transitif membutuhkan kata kerja yang mengalami afiksasi $m e \eta--i$. Argumen pertama yang berfungsi sebagai subjek berupa kata benda, begitu juga pada fungsi objeknya.

5)

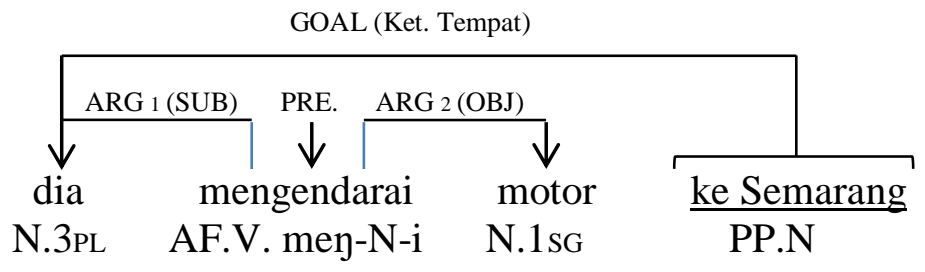

Pada data (5) afiksasi dari morfem mey- - $i$ membentuk kata kerja yang memiliki pelaku pekerjaan dan membutuhkan objek yang dikerjakan. Morfem mey- $-i$ memiliki makna suatu kegiatan yang dilakukan terhadap sesuatu. Argumen pertama berupa kata benda manusia kata ganti orang ketiga sebagai FREED1, sedangkan argumen kedua merupakan kata benda tak bernyawa sebagai FREED2. Peran dari kalimat data (5) sama dengan SVO pada data sebelumnya. Sedangkan 'ke Semarang' menjadi ADJ dari predikat.

\section{Argumen Kata Benda-Preposisi}

Sama halnya dengan kasus pada data (5), bahwa predikat transitif di bawah ini membutuhkan dua argumen, yakni kata benda dan preposisi. Untuk membentuk kata kerja yang membutuhkan dua argumen biasanya dengan menambahkan afiksasi pada kata kerjanya, namun berbeda pada temuan data di bawah ini.

6)

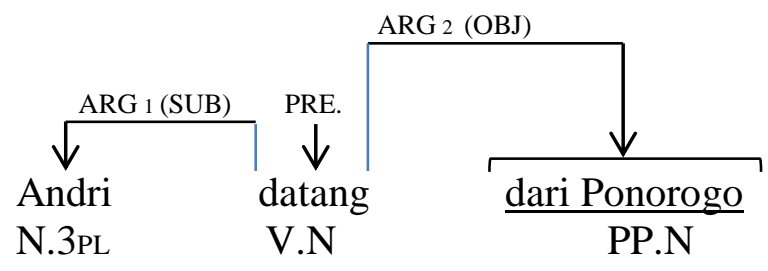


Pola argumen pada data (6) yakni kata benda persona dimiliki argumen pertama atau [FREED 'ANDRI'], sedangkan argumen kedua berupa frasa preposisi. Argumen kedua memiliki peran sebagai objek dari predikat 'datang'. Kata 'datang'tidak membutuhkan afiksasti untuk memiliki dua argumen. Karena pada dasarnya kata kerja ini membutuhkan dua argumen, misalnya kita menghilangkan argumen kedua seperti 'Andri datang' maka kalimat tersebut kurang lengkap. Oleh karena itu dibutuhkan argumen kedua yang memiliki peran sebagai frasa preposisi untuk membentuk sebagai fungsi objek dengan [FREED 'PONOROGO'].

\section{Argumen Penyerta}

Penyerta argumen merupakan objek yang kedua atau argumen ketiga objek theme. Perdikat pada kalimat ini membutuhkan tiga argumen untuk membentuk struktur kalimat benar. Predikat pada data (7) mengalami afiksasi mey--kan dengan klasifikasi sebagai berikut:

7)

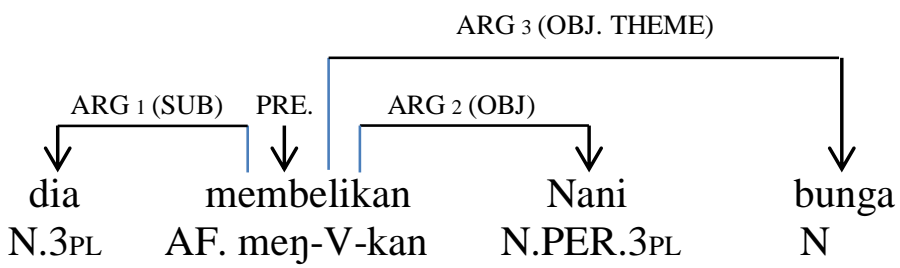

Pola kalimat pada data (7) menggunakn peran SVOO. Predikat 'membelikan' membutuhkan tiga argumen berupa kata benda sebagai argumen pertama [FREED 'DIA'] berupa kata ganti orang ketiga. Objek berkedudukan sebagai argumen kedua [FREED 'NANI'] berupa pronomina orang ketiga yang berasal dari kata benda memiliki peran penderita dari subjek. Sedangkan OBJEKØ (objek theme) dibutuhkan predikat sebagai kategori penyerta dari objek [FREED 'BUNGA'].

\section{Argumen Tersembunyi}

Pola pada temuan data (8) ini keluar dari struktur tatabahasa Indonesia karena ada proses penghilangan objek distu. Sebagaimana pada data (7) bahwa predikat yang mendapatkan afiksasi mey- -kan akan mengalami perubahan argumen dari pembentukan struktur kalimat tanpa adanya proses afiksasi atau dengan morfem lainnya (Chaer: 2008). 
7)

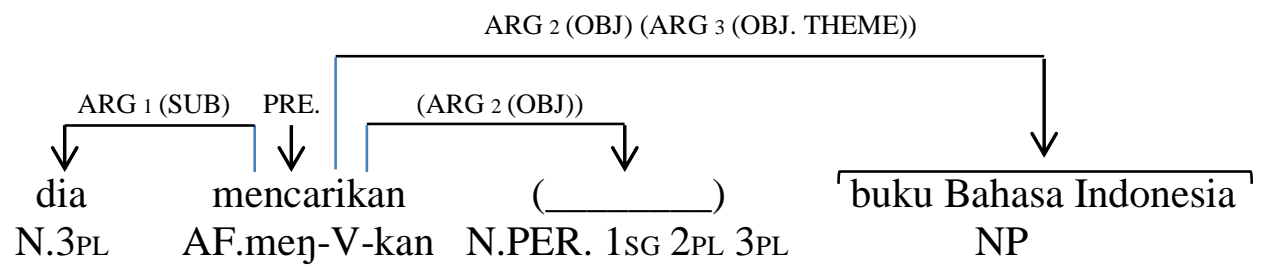

Struktur kalimat di atas menunjukkan fungsi objek diduduki oleh frasa 'buku Bahasa Indonesia'. Subjek memiliki kategori pronominal [FREED 'DIA'] berupa kata ganti orang ketiga, maka seharusnya objek diduduki oleh pronominal FREED 'pronoun' karena predikat dari kalimat tersebut berupa proses berusaha untuk 'cari'. Naka kepada siapa dia melakukan proses kegiatan 'cari' tersebut tidak jelas, bisa terisi oleh kata ganti orang pertama, kedua maupun ketiga. Sedangkan frasa 'buku Bahasa Indonesia' menjadi objek theme dari predikat yang menyertai fungsi objek pronominal. Sehingga jika objek tersebut hilang maka kalimat pada data (7) menjadi tidak padu sebab tidak ada kejelasan proses tersebut untuk [FREED 'PRON']. Namun pada kasus bahasa Indonesia ini sudah umum terjadi penyembunyian objek dari predikat yang membutuhkan tiga argumen.

\section{Argumen Berdasarkan LFG}

Argumen di Indonesia cenderung tidak terstruktur dan lebih kompleks. Foley dan Olson 1985, Butt 1995 dan Durie 1997 dalam Iwayan Arka (2014) mengatakan bahwa komplemen yang komples memiliki struktur ketat yang meliputi adanya $\mathrm{X}$ COMP dengan penggunaan VP yang lebih kompleks. Struktur tersebut terjadi jika VP harus berbagi komplemen dengan subjek yang sama. Bukti menunjukkan struktur VP tidak ketat di (7) dan sebelumnya. Tidak seperti kasus data sebelumnya yang masih menggunakan konsep SVC, pada hal ini meluas kepada OBJ yang berfungsi sebagai XCOMP sekaligus menjadi predikat untuk yang lain. Kombinasi terjadi pada argumen yang berfungsi sebagai SUBJ berikut.

8)

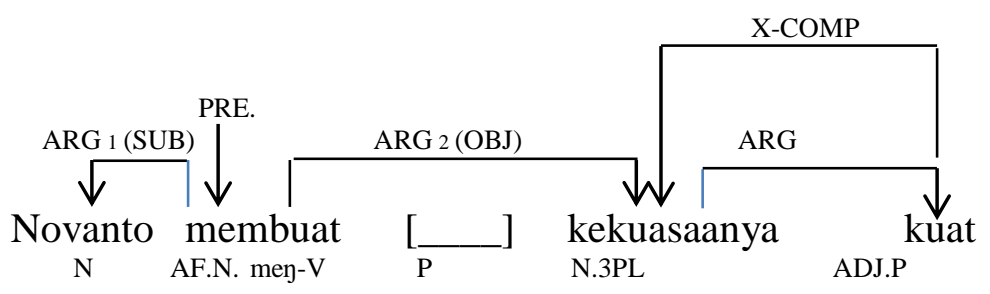


Data di atas menunjukkan bahwa 'Novanto' menjadi subjek darifungsi predikat 'membuat'. ARG2 merupakan argumen dari PRE. karena kata 'membuat' membutuhkan dua argumen. Kata ini termasuk kata aktif transitif, namun tidak bisa dibalik menjadi kalimat pasif. Sedangkan 'kuat' merupakan ajektif yang menjadi fungsi predikat dari Novanto. Kata 'kuat' termasuk X-COMP karena fungsi ini memiliki subjek yang sama. ARG 2 merupakan COMP dari PRE. yang menjadi FREED. Kata yang membentuk XCOMP harus memiliki fungsi subjek yang sama dengan fungsi predikat sebelumnya.

9) C-Str

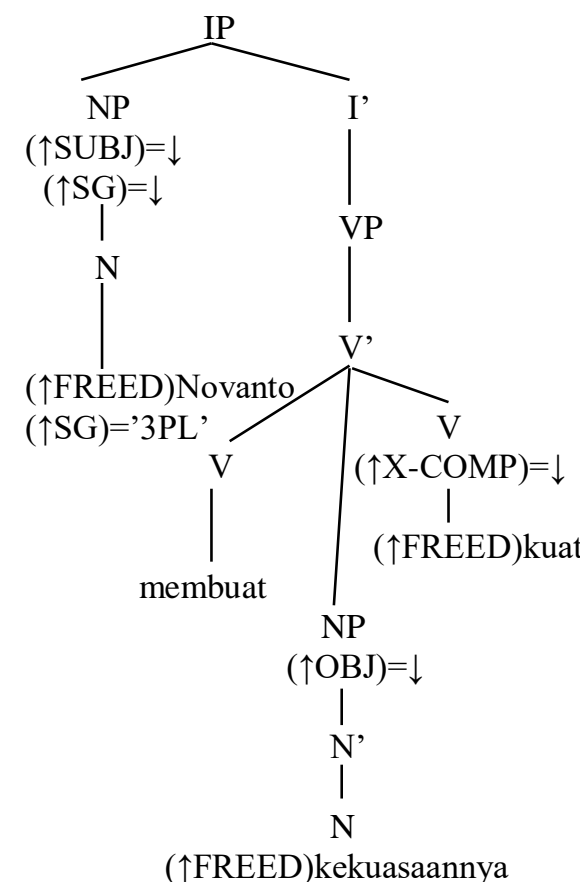

10) F-Str

FREED 'DUGA' <SUBJ, OBJ, X-COMP>

SUBJEK [FREED 'NOVANTO']

OBJEK [FREED 'KEKUASAAN']

$\mathrm{X}$-COMP $\left[\begin{array}{l}\text { FREED 'KUAT' } \\ \text { SUBJ 'KEKUASAAN }\end{array}\right]$

Pada C-Str menjelaskan bahwa kalimat tersebut berupa infleksional kemudian terbagi menjadi teori X-Bar. Frasa nomina menunjukkan bahwa subjek yang menginduk sebelumnya masuk ke dalam sebuah kalimat yang menunjukkan 'Novanto' kemudian sama dengan subjek dibawah dengan tanda $(\uparrow S U B J)=\downarrow$, begitu juga kategori kata ganti orang $(\uparrow S G)=\downarrow$. Selanjutnya FREED dari nomina yang sebelumnya menjadi subjek pada sebuah kalimat 'Novanto' adalah 'Novanto'. Begitu pula yang terjadi pada FREED 'kekuasaan' dengan tanda penunjuk $(\uparrow \mathrm{OBJ})=\downarrow$ dan 'kuat' yang menjadi penunjuk sebagai X-COMP.

Bentuk dari FREED X-COMP berupa objek dari fungsi predikat yang sebelumnya menjadi OBJ. konsep ini muncul karena kedua predikat tersebut memiliki 
subjek yang sama, yakni FREED 'Novanto'. Kemunculan ini terjadi karena proses membuat perubahan yang terjadi pada V' menjadi NP pada pola X-Bar.

\section{PEMBAHASAN}

Penelitian ini mendukung teori TLF Darlimple (2001) dalam menganalisa struktur klausa yang digunakan oleh berita daring Merdeka.com. Kosmas (2015) mengatakan bahwa bahasa Manggarai tidak memiliki pasif morfologis, namun pasif secara semantik dengan menambahkan preposisi ke 'oleh'. Bahasa Indonesia memiliki bentuk pasif morfologis dengan imbuhan afiks di- yang menempel pada verba. Penelitian mendukung pendapat Sawardi (2018) bahwa preposisi dapat mengalami pelesapan karena faktor kejelasan argumen. Kebaharuan penelitian ini terletak pada pelesapan argumen oblik pada penggunaan kalimat di dalam media berita daring Merdeka.com. Berdasarkan analisis data disimpulkan konstruksi ciri transitifitas sebagai berikut; 1) preposisi mengalami pelesapan pada argumen personal, 2) preposisi tetap ada penunjuk lokasi dan benda tak bergerak, 3) argumen kedua tetap ada dari unsur gramatikal, dapat dilesapkan dengan dari fungsi semantik, 4) argumen oblik dilesapkan dari unsur gramatika.

\section{SIMPULAN}

Pola kalimat yang digunakan oleh berita daring Merdeka.com memiliki karakteristik struktur yang sangat luas. Pola tersebut mengalami proses afiksasi pada fungsi predikat untuk menentukan argumennya. Beberapa kata tidak mengalami proses afiksasi untuk membentuk argumen lebih dari dua. Selain itu subjek yang sama di induk kalimat dan anak kalimat membentuk X-Comp sering terlihat pada kata formal pada kasus data penggunaan kalimat pada media massa daring Merdeka.com.

\section{DAFTAR PUSTAKA}

Alwi, S., D., \& Hans L., A., M., M. (1998). Tata Bahasa Baku Bahasa Indonesia. Departemen Pendidikan dan Kebudayaan Republik Indonesia.

Anjarningsih, H. Y., \& Bastiaanse, R. (2011). Verbs and time reference in Standard Indonesian agrammatic speech. Aphasiology. https://doi.org/10.1080/02687038.2011.626844

Arka, I. W. (2014). Double and Backward Control in Indonesian: An LFG Analysis. Proceedings of the LFG14 Conference.

Chaer, A. (2003). Tata Bahasa Praktis Bahasa Indonesia. In Rineka Cipta. 
Dalrymple, M. (2006). Lexical Functional Grammar. In Encyclopedia of Language \& Linguistics. https://doi.org/10.1016/B0-08-044854-2/02043-5

Katamba, F. (1993). Morphology (Modern Linguistics Series) (1st ed.). London: Bedford/st Martins.

Keraf, G. (1984). Tata Bahasa Indonesia. Ende Flores: Nusa Indah.

Kosmas, J. (2017). Konstruksi Pasif Bahasa Manggarai: Sebuah Analisis Leksikal Fungsional. RETORIKA: Jurnal Ilmu Bahasa. https://doi.org/10.22225/jr.1.1.16.108-122

Polinsky, M., \& Potsdam, E. (2008). The syntax and semantics of wanting in Indonesian. Lingua. https://doi.org/10.1016/j.lingua.2007.08.005

Purwo, K. (1989). Deiksis Dalam Bahasa Indonesia. Jakarta: Balai Pustaka.

Sawardi, F. X. (2018). Pelesapan Preposisi dalam Gramatika Bahasa Indonesia. SEMIOTIKA: Jurnal Ilmu Sastra Dan Linguistik. https://doi.org/10.19184/semiotika.v18i2.5382

Sudaryanto. (2015). Metode dan Aneka Teknik Analisis Bahasa: Pengantar Penelitian Wahana Kebudayaan secara Linguistis. Yogyakarta: Duta Wacana University Press.

Sugono, D. (1985). Pelepasan Subjek dalam Bahasa Indonesia. Retrieved from http://repositori.kemdikbud.go.id/3306/1/Pelesapan subjek dalam bahasa indonesia.pdf 